\author{
ヒト顆粒球拈よび単球のスーパーオキサイド産生に括 \\ けるセリンプロテアーゼの役割
}

\author{
北川誠一・高久史麿*
}

\begin{abstract}
Role of serine proteases in superoxide production by human polymorphonuclear leukocytes and monocytes The possible participation of proteases in superoxide $\left(\mathrm{O}_{2}^{-}\right)$production by human polymorphonuclear leukocytes (PMN) and monocytes was explored using various protease inhibitors and substrates. Protease inhibitors used included naturally occurring inhibitors of serine proteases and synthetic inhibitors that modify the active site of serine proteases. Substrates used were synthetic substrates of the chymotrypsin type as well as trypsin type of protease. All these inhibitors and substrates inhibited $\mathrm{O}_{2}{ }^{-}$production by human PMN and monocytes induced by cytochalasin $\mathrm{E}$ and concanavalin A, though PMN were more sensitive to these inhibitors and substrates than monocytes. Inhibition appeared rapidly even when the inhibitors were added at the same time as the stimulants, during the induction time of $\mathrm{O}_{2}^{-}$production or at the time of maximum $\mathrm{O}_{2}{ }^{-}$production, whereas much greater inhibition was observed when the cells were preincubated with the inhibitors. These observations suggest that enzymatically active serine proteases are essential for these phagocytic cells to initiate and maintain the $\mathrm{O}_{2}{ }^{-}$production in response to the stimuli. The inhibitory effect of the inhibitor and substrate for chymotrypsin type protease was greater than that of those substances for trypsin type protease. Macromolecular inhibitors also inhibited the $\mathrm{O}_{2}{ }^{-}$production. These findings suggest that the serine proteases involved in the $\mathrm{O}_{2}^{-}$production by human PMN and monocytes are similar to chymotrypsin rather than trypsin, and are possibly located at the cell surface membrane.
\end{abstract}

Seiichi Kitagawa - Fumimaro Takaku Department of Medicine, Jichi Medical School

顆粒球および単球から放出されるスーパーオキサイド $\left(\mathrm{O}_{2}^{-}\right)$は, きわめて反応性に富み, 殺菌過程および炎症 局所に扣ける組織損傷のうえできわめて重要な役割を果 たしている1).これらの細胞による $\mathrm{O}_{2}^{-}$産生は, 必ずし も食作用を必要とせず, 種々の膜作用物質によって誘導 される2).

今回，われわれは concanavalin A (Con A) と cytochalasin E (Cyt E) によって誘導されるヒト顆粒球 牤よび単球の $\mathrm{O}_{2}{ }^{-}$産生の過程にセリンプロテアーゼが 関与している可能性を見いだしたので報告する.

\section{方 法}

\section{（1） 細胞調整}

健康成人より得たヘパリン加静脈血に等量の $3 \%$ デキ ストラン生食を加え, 室温に約 30 分静置して大部分の赤 血球を沈降させて除いた，白血球を多く含む上清を Ficoll-Conray に重層し, 此重遠沈法によって顆粒球分画 (顆粒球 $99 \%$ 以上) と単核球分画（単球 $15 \sim 25 \%$, リン ハ球 $75 \sim 85 \%$, 顆粒球 $1 \%$ 以下）に分離した. 顆粒球分

* 自治医科大学第一内科学教室
画に含まれている赤血球は溶血操作によって除去した. 一方, McCoy's 5 A に浮遊させた単核球 $\left(5 \times 10^{6} / \mathrm{ml}\right)$ に carbonyl iron を加光, $37^{\circ} \mathrm{C} 30$ 分粰置後, 食細胞を magnet で除去して,リンパ球分画（リンパ球 $99 \%$ 以 上）調整した。これらの細胞は，すべて Hepes-生食

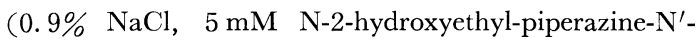
2-ethane-sulfonic acid, $\mathrm{pH}$ 7.4) に浮遊させた.

(2) $\mathrm{O}_{2}{ }^{-}$の測定

分光光度計用の $1 \mathrm{ml}$ cuvette $飞 2 \mathrm{mM}$ glucose, $1 \mathrm{mM}$ $\mathrm{CaCl}_{2}, \quad 66 \mu \mathrm{M}$ ferricytochrome $\mathrm{C}$, 細胞浮遊液 (2-4× $10^{5}$ 顆粒球 $/ \mathrm{m} l$ または $1.2-2 \times 10^{6}$ 単核球 $\left./ \mathrm{m} l\right)$ 打よび セリンプロテアーゼの阻害剤または人工基質を加光, 総 量 $0.99 \mathrm{ml}$ とした。 これらの反応液を $37^{\circ} \mathrm{C} ・ 3$ 分（セ リンプロテアーゼの阻害剤）または10分（セリンプロテ アーゼの人工基質) 邲置後, Con A ( $5 \mu l$, 最終濃度 50 $\mu \mathrm{g} / \mathrm{ml})$ と Cyt E $(5 \mu l$, 最終濃度 $5 \mu \mathrm{g} / \mathrm{ml})$ を同時に 加光，産生された $\mathrm{O}_{2}^{-}$を ferricytochrome $\mathrm{C}$ の還元 (550〜 540 nm) によって測定した ${ }^{3,4)}$. これらの反応は, 2 波長分光光度計（日立 557）に取りつけた恒温セルホ ルダー中 $\left(37^{\circ} \mathrm{C}\right)$ で行わせ, レコーダを用いて反応の time course を描かせた. Con A 扤よび Cyt E の添加 
(A)

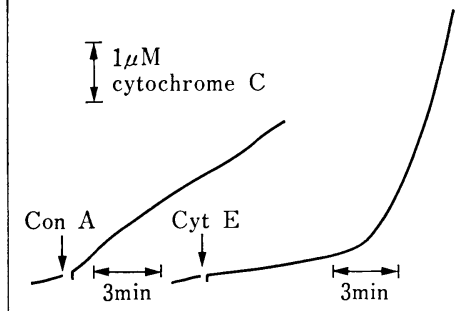

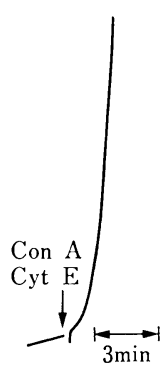

(B)

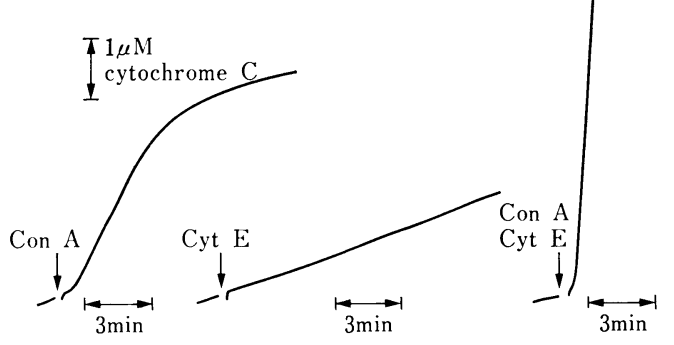

図 1 顆粒球 (A) 打上び単球 (B) の $\mathrm{O}_{2}^{-}$産生反応

顆粒球 $5 \times 10^{6} / \mathrm{m} l$. 単核球 $1.2 \times 10^{6} / \mathrm{m} l$ (単球 $25 \%$ ). 却: Con A $50 \mu \mathrm{g} / \mathrm{m} l$ 単独添加. 中央: Cyt E $5 \mu \mathrm{g} / \mathrm{m} l$ 単独添加. 右 : Con A $50 \mu \mathrm{g} / \mathrm{ml}$ と Cyt E $5 \mu \mathrm{g} / \mathrm{m} l$ 资同時飞添加.
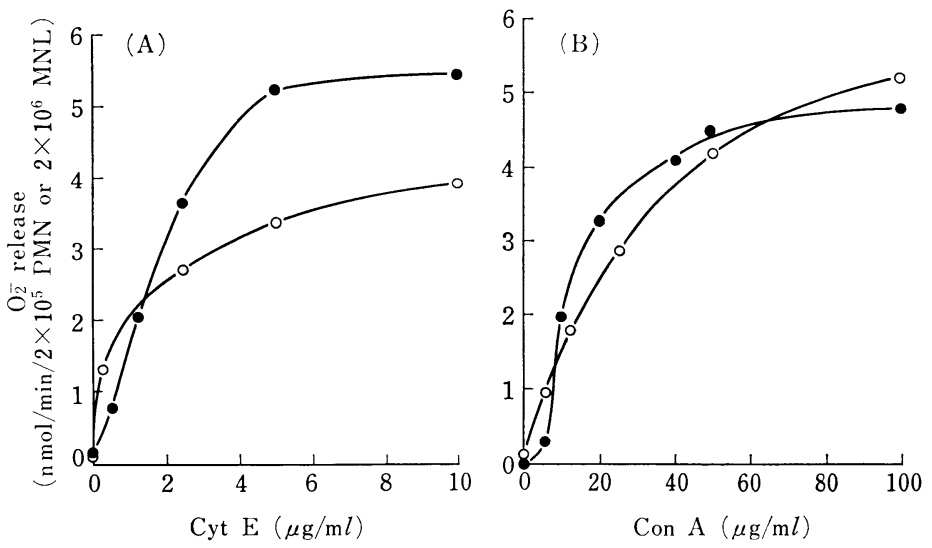

図 2 Con $\mathrm{A}$ と $\mathrm{Cyt} \mathrm{E}$ の同時添加による $\mathrm{O}_{2}^{-}$産生促進効果

(A) Con A $(50 \mu \mathrm{g} / \mathrm{ml})$ と種々の濃度のCyt E を同時に添加

(B) Cyt E $(5 \mu \mathrm{g} / \mathrm{m} l)$ と種々の濃度のCon A を同時に添加

$\bigcirc$ : 顆粒球 $2 \times 10^{5} / \mathrm{ml}$.

: 単核球 $2 \times 10^{6} / \mathrm{m} l$

(A)

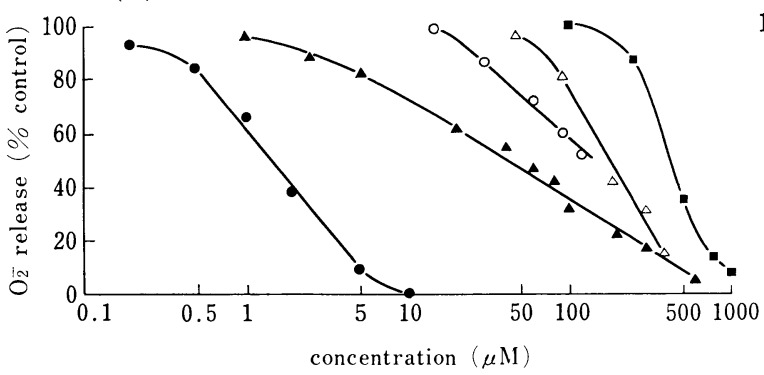

(B)

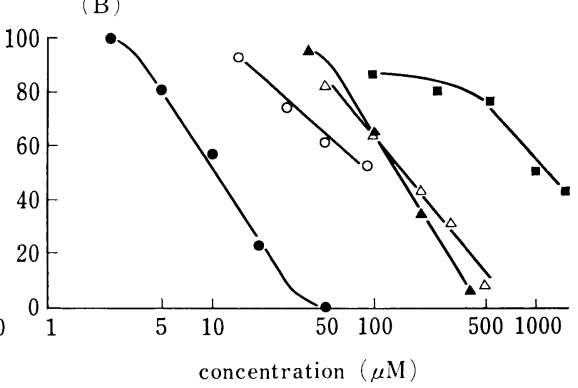

図了種々のセりンプロテアーゼ阻害剂によっ顆粒球 (A) 扣よび単球 (B) の $\mathrm{O}_{2}$ - 産生の阻害 細胞浮遊液に種々のセリンプロテアーゼ阻害剤空加光, $37^{\circ} \mathrm{C} \cdot 3$ 分孵置後, Con $\mathrm{A}(50 \mu \mathrm{g} / \mathrm{m} l)$ と Cyt E $(5 \mu \mathrm{g} / \mathrm{ml})$ を同時に添加.

๑ : TPCK, $\bigcirc$ : aprotinin. $\triangle$ : TLCK. $\triangle$ : SBTI.

PMSF

によって誘導される cytochrome C の還元は, superoxide dismutase $(20 \mu \mathrm{g} / \mathrm{ml})$ によって完全に阻害され, $\mathrm{O}_{2}$ - に特異的な反応であると考えられた， $\mathrm{O}_{2}$-の産生速 度は time course の直線部分より算出した。これらの 実験に拈いて，エリスロシンBで調ベた細胞の viability

は95\%以上であった。

結 果

(1) Con A および Cyt E によって誘導される顆 粒球扣よび単球の $\mathrm{O}_{2}^{-}$産生反応 


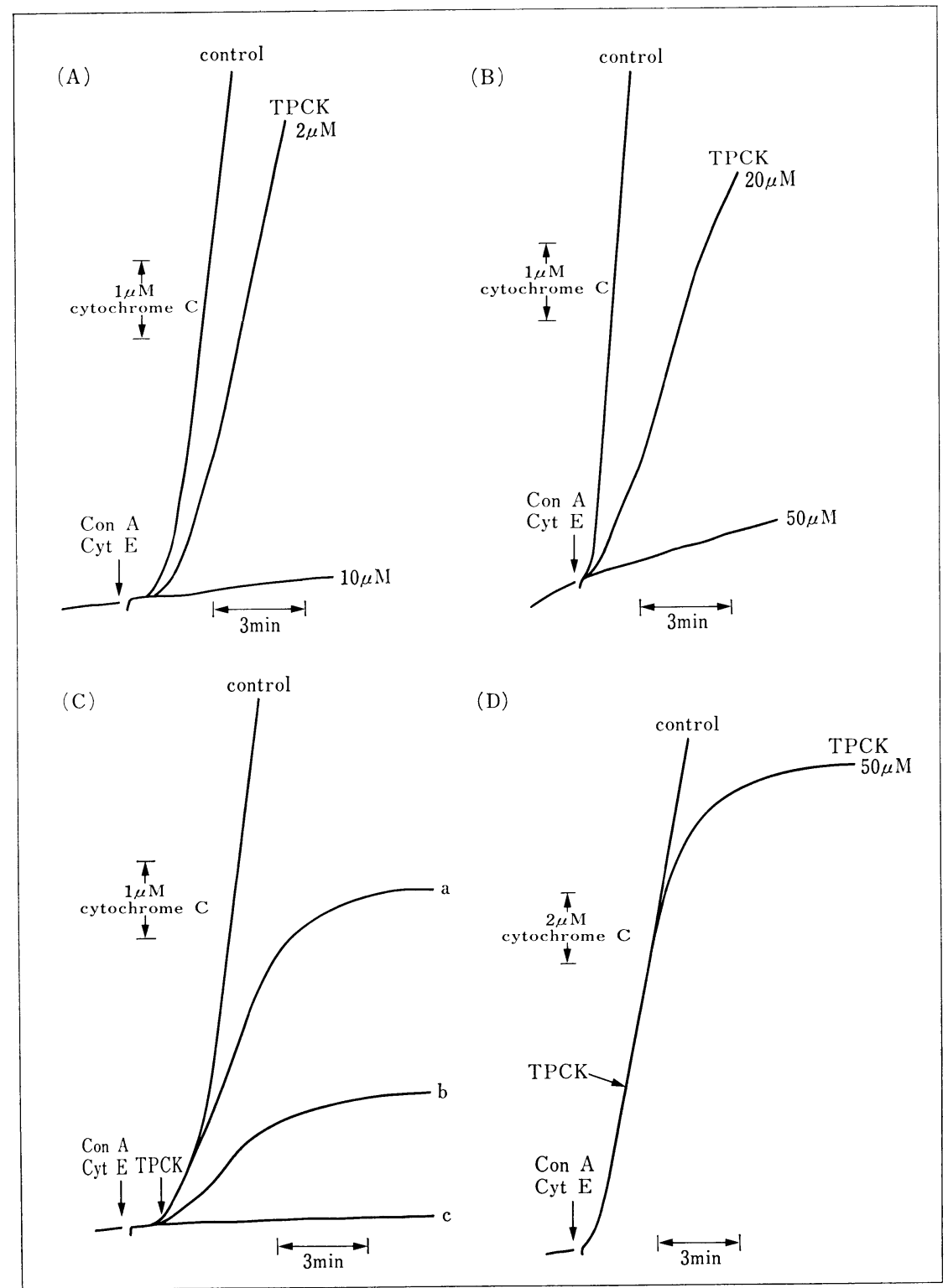

图 4 TPCK による顆粒球扣よび単球の $\mathrm{O}_{2}^{-}$産生の阻害

(A) 顆粒球 $\left(2 \times 10^{5} / \mathrm{ml}\right)$

(B) 単核球 $\left(2 \times 10^{6} / \mathrm{m} l\right)$ V TPCK を加光, $37^{\circ} \mathrm{C} \cdot 3$ 分卯置後, Con A $(50 \mu \mathrm{g} / \mathrm{m} l)$ と Cyt E $(5 \mu \mathrm{g} / \mathrm{m} l)$ を同時に添加

(C) Con A $(50 \mu \mathrm{g} / \mathrm{m} l)$ 打よび Cyt E $(5 \mu \mathrm{g} / \mathrm{m} l)$ 添加（a） 1 分後, （b ) 同時, (c) 5 分前に TPCK $(10 \mu \mathrm{M})$ を顆粒球 $\left(2 \times 10^{5} / \mathrm{m} l\right)$ 浮遊液に添加

(D) 単球 (単核球 $1.75 \times 10^{6} / \mathrm{ml}$ ) の $\mathrm{O}_{2}^{-}$産生が最大に達したときに TPCK $(50 \mu \mathrm{M})$ を途中添加

Con A $(50 \mu \mathrm{g} / \mathrm{m} l)$ 扰よび Cyt E $(5 \mu \mathrm{g} / \mathrm{m} l)$ を同時に添加

Con A および Cyt E は顆粒球ばかりでなく, 単球 にも作用して $\mathrm{O}_{2}^{-}$産生を誘導した ${ }^{5 \sim 8)}$. これらの細胞に よる $\mathrm{O}_{2}^{-}$産生は, Con $\mathrm{A}$ と Cyt E を同時に添加する ことにより，著明に増強された（図 1 ).

しかし，Con A および Cyt E に対する反応には両細 胞間で相異が認められ, 顆粒球は Con A よりもCyt E
に対してょく反応し, 単球は Cyt E よりも Con A に 対してよく反応した。 さらに，Con A によって誘導さ れた顆粒球の $\mathrm{O}_{2}{ }^{-}$産生は持続的で, 直線的に増加する 一方, 単球の $\mathrm{O}_{2}{ }^{-}$産生は一過性で $4 \sim 5$ 分後にはいち じるしく減弱した．これらの細胞による $\mathrm{O}_{2}^{-}$産生は, Cyt $\mathrm{E}$ 和よび Con A の濃度に依存して増加した（図 

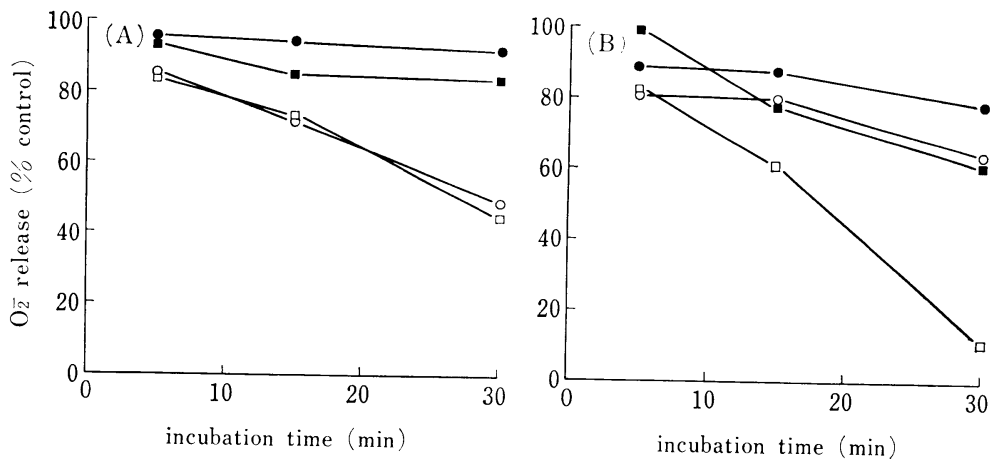

図 5 顆粒球 (A), 単球 (B) の $\mathrm{O}_{2}$ 阵生に及活す TPCK 扣よび PMSFの 影響

細胞浮遊液に TPCK \&たは PMSF を加え， $37 \mathrm{C} て ゙ 5$ 分・15分末た は 30 分粰置後, Con A $(50 \mu \mathrm{g} / \mathrm{ml})$ とCyt E $(5 \mu \mathrm{g} / \mathrm{ml})$ を同時に添加 (A)

: $100 \mu \mathrm{M}$ PMSF $\square: 0.5 \mu \mathrm{M}$ TPCK

(B) $\bullet: 250 \mu \mathrm{M}$ PMSF. $\bigcirc: 500 \mu \mathrm{M}$ PMSF. $\square: 5 \mu \mathrm{M}$ TP CK

2).また，細胞数にも比例して増加した。リンパ球分岫 (リンパ球 $99 \%$ 以上) に Con A と Cyt E を同時に添加 しても $\mathrm{O}_{2}^{-}$産生はほとんど垫められなかった。したが って, 単核球分画に打ける $\mathrm{O}_{2}^{-}$の産生は単球によって 行なわれると考えられた。

（2）セリンプロテアーゼ阻害剤による顆粒球および 単球の $\mathrm{O}_{2}^{-}$産生の阻害

図 3 に示すように, 顆粒球および単球の $\mathrm{O}_{2}{ }^{-}$産生は ともに種々のセリンプロテアーゼ阻害剂によって濃度依 存性に抑制された. L-1-tosylamido-2-phenylethyl-chloromethyl ketone (TPCK) による典型的な阻害作用を図 4 に示した. 種々の時点で TPCK を添加すると, 添加後 すみやかに阻害作用が認められ，特に細胞を TPCK で 前処置すると阻害作用は一層強くなった。ささらに， $\mathrm{O}_{2}$ 産生速度が最大に達したときに，TPCK を途中添加し ても，すみやかに阻害作用が認められた。同様な結果 は, その他の阻害剤でも認められた。

図 5 に示すように, TPCK および phenylmethylsulfonylfluoride (PMSF) による阻害作用は, 細胞との卯: 置時間をながくするとさらに強くなった。一般に顆粒球 は, 単球に比し，セリンプロテアーゼ阻害剤に対して感 受性が高い傾向にあった．顆粒球に対する阻害作用の強 さは TPCK $>$ N- $\alpha$ - $p$-tosyl-L-lysine-chloromethyl ketone $($ TLCK) $>$ aprotinin $>$ soybean trypsin inhibitor (SBTI) $>\mathrm{PMSF}$ であり，単球に対する阻害作用の強さは $\mathrm{TPCK}>$ aprotinin $>\mathrm{TLCK}=\mathrm{SBTI}>\mathrm{PMSF}$ であった (戍 3 ).

顆粒球と PMSF を $37^{\circ} \mathrm{C} \cdot 5$ 分孵置後, 細胞を洗浄 して反応液から PMSF を除去すると, $\mathrm{O}_{2}$ - 産生は著明

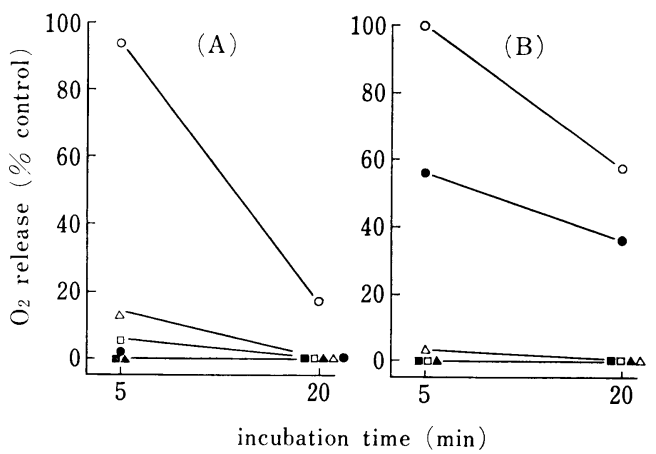

図 6 セリンプロテアーゼ阻害剂除去による顆粒球 (A) 打よび単球 (B) の $\mathrm{O}_{2}^{-}$産生の回復 細胞浮遊液にプロテアーゼ阻害剤を加え, $37^{\circ} \mathrm{C} \cdot 5$ 分木たは20分卯孚置後, 細胞を 2 回洗 浄して, 阻害剤を反応液から除去した。 open symbols は洗浄した細胞の $\mathrm{O}_{2}{ }^{-}$産生を示し, solid symbols は洗浄しなかった細胞の $\mathrm{O}_{2}{ }^{-}$ 産生を示す。 $\mathrm{O}_{2}$ - の産生は, Con A (50 $\left.\mu \mathrm{g}\right)$ $\mathrm{ml})$ と Cyt E $(5 \mu \mathrm{g} / \mathrm{ml})$ を同時に添加与る ことによって誘導した。

(A) $\bigcirc, \bullet: 1 \mathrm{mM}$ PMSF. $\square, \square: 10 \mu \mathrm{M}$ TPCK, $\triangle, \triangle: 500 \mu \mathrm{M}$ TLCK

(B) $\bigcirc, \bullet: 1 \mathrm{mM}$ PMSF. $\square, \boldsymbol{\square}: 50 \mu \mathrm{M}$ TPCK. $\triangle, \Delta: 500 \mu \mathrm{M}$ TLCK

に回復した(図 6 A). 同様な結果は軽度であるが, TLCK および TPCK による阻害作用でも認められたが，孵置 時間をながくすると回復は認められなくなった，PMSF による阻害も, 顆粒球を $1 \mathrm{mM}$ PMSF で $37^{\circ} \mathrm{C} ・ 40$ 分, 前処置すると $\mathrm{O}_{2}^{-}$産生の回復は消失した．同様な結果 は単球でも認められた（図 6 B). 

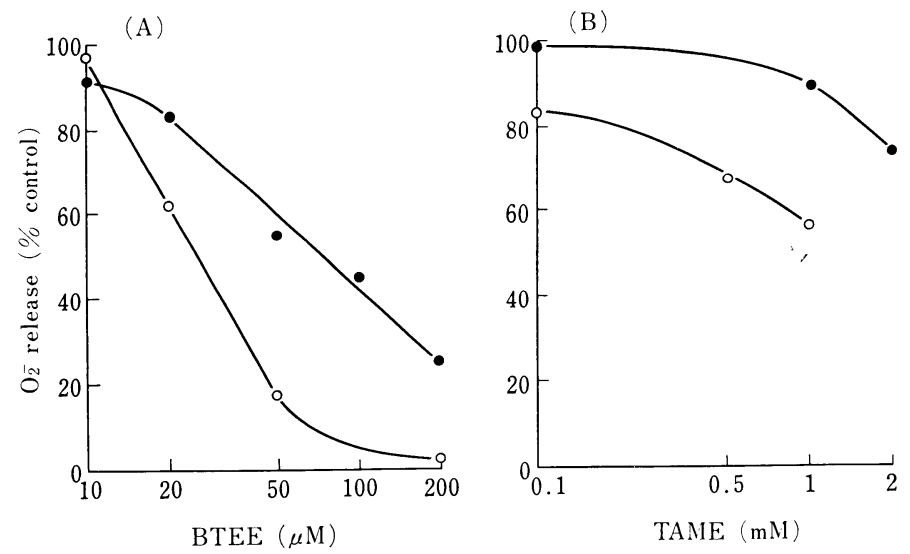

图 7 セりンプロテアーゼの人工基質による顆粒球扣よび単球の $\mathrm{O}_{2}{ }^{-}$ 産生の阻害

細胞浮遊液に（A） BTEEょたは（B） TAMEを加え， $37^{\circ} \mathrm{C}$

10 分餒置後, Con A $(50 \mu \mathrm{g} / \mathrm{ml})$ とCyt E $(5 \mu \mathrm{g} / \mathrm{ml})$ を同時

に添加

$\bigcirc$ : 顆粒球.

: 単球

（3） セリンプロテアーゼの人工基質による顆粒球お よび単球の $\mathrm{O}_{2}^{-}$産生の阻害

顆粒球および単球の $\mathrm{O}_{2}{ }^{-}$産生は, N-benzoyl-L-tyrosine ethyl ester (BTEE) および $p$-tosyl-L-arginine methyl ester (TAME) によって濃度依存性に抑制された (図 7 )。阻害作用の強さは BTEE > TAME であった. また，阻害剂に対すると同様，単球に比し，顆粒球は人 工基質に対して感受性が高い傾向にあった。

\section{考 察}

顆粒球打よび単球の $\mathrm{O}_{2}^{-}$産生は, 種々のセリンプロ テアーゼ阻害剂执よび人工基質によって抑制された。 こ れらの事実は, 顆粒球扣よび単球の $\mathrm{O}_{2}^{-}$産生にセリン プロテアーゼが関与している可能性を示唆している。顆 粒球扣よび単球の $\mathrm{O}_{2}{ }^{-}$産生に対する阻害作用は, キモ トリプシン阻害剂である TPCK がトリプシン阻害剂で ある TLCK よりもきわめて強く, 一方, 人工基質を用 いた実験でも，キモトリプシンの人工基質である BTEE が，トリプシンの人工基質である TAME よりもきわめ て強かった (12) $^{9 \sim}$

これらの事実は，本プロテアーゼがトリプシンより も，むしろキモトリプシンに類似していることを示唆し ている，さらに，細胞膜を透過することは困難と思われ る高分子の阻害剂 (aprotinin および SBTI) によって もすみやかに $\mathrm{O}_{2}{ }^{-}$の産生が抑制されることより，本プ ロテアーゼは顆粒球および単球の表面細胞膜に局在する ものと考えられる ${ }^{13,14)}$. 顆粒球と単球との間に, セリン プロテアーゼ阻害剂および人工基質に対する感受性に相 異が認められる，この相異の原因としてつぎの 2 点が考 えられる。
(1) $\mathrm{O}_{2}{ }^{-}$産生に関与するプロテアーゼは顆粒球と単 球とで異なっている.

(2) 顆粒球と単球とで, その $\mathrm{O}_{2}^{-}$産生機構に相異が 存在する。

最近のわれわれの研究は, 顆粒球と単球とでその $\mathrm{O}_{2}{ }^{-}$ 産生機構に相異が存在することを示している ${ }^{15)}$.

PMSF，TPCK，执よび TLCK は，七リンプロテア 一ゼの活性中心に存在するセリンまたはヒスチジン残 基と不可逆的に結合し，プロテアーゼ活性を失活させ る $^{9,16)}$. しかし，次式に示すように，その反応の中間体 として可逆的な複合体を形成することが認められてい $ろ^{9,16)}$.

酵素 + 阻害剤

酵素一阻害剂複合体（非共有結合，不活性）

$\downarrow$ 不可逆的

酵素一阻害剂（共有結合，不活性）

これらの反応が，膜表面に存在するプロテアーゼと阻 害剂との間で行われていると考えるならば，阻害剤を除 去した際に認められる $\mathrm{O}_{2}{ }^{-}$産生の軽度の回復は, 可逆 的な酵素——阻害剂複合体の存在で説明することができ る.さらに，この $\mathrm{O}_{2}^{-}$産生の回復は，細胞と阻害剂を 十分に孵置した場合には消失し，また，阻害剤による抑 制は時間依存性であることより, 本プロテアーゼは膜表 面に活性型で存在していると考劣られる.

本プロテアーゼが， $\mathrm{O}_{2}{ }^{-}$産生酵素である $\mathrm{NAD}(\mathrm{P}) \mathrm{H}$ oxidase の活性化にどのような形で関与しているのか, また，本プロテアーゼの基質がなんであるか，今後に残 された問題である. 


\section{文 献}

1）北川誠一, 高久史䗪：臨床免疫 $10: 522-538$, 1978.

2) 中川原章, 竹重公一朗：代謝 $14: 985-995,1977$.

3) Nakagawara, A., Nabi, B.Z.F., Minakami, S.: Clin. Chim. Acta. 74 : 173-176, 1977.

4) Kitagawa, S., Takaku, F., Sakamoto, S.: J. Clin. Invest. $65: 74-81,1980$.

5) Romeo, D., Zabucchi, G., Rossi, F.: Nature New Biol. 243 : 111-112, 1973.

6) Nakagawara, A., Minakami, S.: Biochem. Biophys. Res. Commun. 64 : 760-767, 1975.

7) Goldstein, I.M., Cerqueira, M., Lind, S., Kaplan, H.B.: J. Clin. Invest. 59 : 249-254, 1977.

8) Kitagawa, S., Takaku, F., Sakamoto, S.: FEBS Lett. $107: 331-334,1979$.

9) Shaw, E.: The Enzymes. P.D. Boyer, ed. Acade- mic Press. Inc., New York, I: 91-146, 1970.

10) Schoellman, G., Shaw, E.: Biochemistry $2: 252$ 255, 1963.

11) Shaw, E., Mares-Guia, M., Cohen, W.: Biochemistry $4: 2219-2224,1965$.

12) Hummel, B.C.W.: Can. J. Biochem. Physiol. 37: 1393-1399, 1959.

13) Trautschold, I., Werle, E., Zickgraf-Rüdel, G. : Biochem. Pharmacol. 16 : 59-72, 1967.

14) Kowalski, D., Leary, T.R., McKee, R.E., Sealock, R.W., Wang, D., Laskowski, M., Jr.: Protease Inhibitors. Fritz, H., Tschesche, H., Greene, L. J., Truscheit, E. ed. Springer-Verlag, Berlin. 311-324, 1974.

15) Kitagawa, S., Takaku, F., Sakamoto, S.: J. Immunol. 125 : 359-364, 1980.

16) Fahrney, D.E., Gold, A.M.: J. Am. Chem. Soc. 85 : 997-1000, 1963. 